\title{
Sorting Through the Advice: A Review of "How-to-Write" Books
}

\author{
Angela Kublik
}

\section{Introduction:}

In Thunder and Lightning: Cracking Open the Writer's Craft, her third installment of advice for would-be writers, Natalie Goldberg recalls her amazement at hearing that a poet friend was writing a book about how to write poetry:

Perhaps I shouldn't be surprised. After all, didn't I do that, too? But I thought I was an anomaly. I see now that there's an entire movement. When Writing Down the Bones came out in 1986, bookstores put it in the reference section. Now, at the end of our millennium, they have separate sections dedicated to books on writing. (43-44)

Indeed, Goldberg is quite correct in suggesting that there is "an entire movement" of books about writing - everything from novels to screenplays to cookbooks - and a trip to the local public library or nearby bookstore quickly confirms her observations. A search of the Edmonton Public Library online catalog under the subject "authorship" locates almost two hundred items with titles such as Sin and Syntax: How to Craft Wickedly Effective Prose (Hale), You Can Write Poetry (Mock), and Writing the Private Eye Novel: A Handbook (Randisi). Chain bookstores such as Chapters provide a similar selection, accompanied by a wide range of journals and other accessories, and even independent bookstores routinely carry two or three dozen titles. Novelist Jack Hodgins has written a book about writing fiction, and former Cosmopolitan editor Helen Gurley Brown imparts her advice for writers in The Writer's Rules. Stephen King's On Writing, 
which is part memoir and part tutorial for the aspiring writer, currently occupies a place on the bestseller list. Perhaps, as Goldberg suggests, "many people now are more interested in the process or way of a writer than in any writer's individual work" (43). If so, the number of books available about writing is a clear reflection of that interest.

But what exactly is being said about writing, and about the "way of the writer," in these books? It became evident as I examined books in this genre that the writing process is being represented in different ways by different authors, and the way in which writing is represented depends, in large part, on how the author views the purpose of writing. Four different representations of the writing process emerged as I read: while some books emphasize the use of writing as a means of self-discovery, others focus on the affective aspects of the writing process; still others concentrate on the craft of writing, and books in the final group focus on how to write "saleable" pieces and then sell them. These four categories form the basis for the discussion that follows.

\section{Books that focus on using writing for self-discovery:}

Books in this category tend to represent the writing process as a method for accessing one's own inner creativity. Examples of this kind of how-to-write book include Julia Cameron's The Right to Write: An Invitation and Initiation into the Writing $\underline{\text { Life and Dorothy Randall Gray's The Soul Between the Lines: Freeing Your Creative }}$ Spirit Through Writing. Both Cameron and Gray emphasize the potential for personal growth and self-discovery through writing, and both suggest that writing can be both spiritual and healing. Gray writes that "I've seen people change jobs, lose weight, heal

old hurts, launch new writing careers, connect with ancestors, close the doors on abusive 
relationships, and find new voices to shape their souls" as the result of the writing exercises included in Soul Between the Lines (xx). Similarly, Cameron, who calls writing "a powerful form of prayer and meditation," writes that "we should write because writing is good for the soul. We should write because writing yields us a body of work, a felt path through the world we live in" (xvi). This view - that writing can be used as a tool for personal growth and healing - underlies the advice about writing that both Cameron and Gray give their readers and shapes the representation of the writing process that they impart.

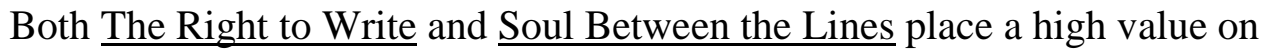
expressive writing - "writing that is in some way connected to the "self'" (Reed 110). Janine Reed would classify both Cameron and Gray as using an "authenticity" approach to expressive writing, a central premise of which is that "writing ability is related to understanding oneself and that good writing must be authentic - a genuine, sincere expression of that self" (111). Writers are advised to express themselves openly and honestly, and to "draw on an inner source of authentic language and voice" when writing (111). To this end, Cameron suggests that writing about personal experience is important because "when we write about our lives we respond to them. As we respond to them we are rendered more fluid, more centered, more agile on our own behalf" (94). Furthermore, many of the writing exercises suggested by both Cameron and Gray encourage readers to explore their own lives, as does this example from $\underline{\text { Soul Between the }}$ Lines:

"I was the first one there." Say this line, close your eyes, and see yourself there. Then write about the circumstance or event that took place around these words. (82). 
The authenticity approach, as outlined by Reed, relies on the underlying notion that each individual has a "true" self, and that writing is simply a matter of listening to that self and putting down what that voice within is saying (120). This notion of a "true self" is evident in Cameron's discussion of voice: “each of us already has a unique voice. We do not need to 'develop' it; rather, we need to discover, or, perhaps better, uncover it" (154).

One result of this emphasis on using the writing process as a tool for personal growth and self-discovery is that little or no emphasis is placed on the product of the writing process - the text itself. Indeed, both Gray and Cameron are quick to differentiate their books from those that provide advice about how to get published. While "there are many fine books on the market that can tell you how to publish, find an agent, or construct stories that sell," Gray writes, "this is not one of them" (xx). This indifference to the text extends beyond an indifference to the publishing industry. Cameron and Gray have little to say about the craft of writing, or about what makes good writing good. In fact, Cameron's advice is to not worry about it: "writing goes much better when we don't work at it so much. When we give ourselves permission to just hang out on the page" (3). This advice re-enforces Cameron's notion of "uncovering" a "true self" and her emphasis on the therapeutic aspects of writing.

\section{Books that address the affective aspects of the writing process:}

The books in this category address the affective aspects of the writing process, such as how to get started, find time to write, and actually write having found the time. Topics concerned with the craft of writing, such as plot development, characterization 
and point of view, are also covered. Books in this category are usually written in the first-person by a working writer whose intent is to offer practical advice to the would-be writer, and these books usually include accounts of the author's own personal experiences. Examples of this kind of how-to-write book include Anne Lamott's Bird by Bird: Some Instructions on Writing and Life and Marcia Golub's I'd Rather Be Writing. Unlike Cameron and Gray - who give the impression that if one listens closely enough to one's inner voice, writing will just flow onto the page, fully formed - both Lamott and Golub admit that they often find the act of writing to be frustrating. Lamott describes sitting down to write this way: "your mental illnesses arrive at the desk like your sickest, most secretive relatives. And they pull up chairs in a semicircle around the computer, and they try to be quiet but you know that are there..." (16). Similarly, Golub writes about avoidance: "The sad truth is that although many people say they would rather be writing, when they sit down at their computers they discover they really would rather be doing the laundry" (4). Both Golub and Lamott suggest ways to get past this initial inertia. Golub recommends using freewriting because "It gets you going. You're not so afraid of starting if you've already started" (32). Lamott talks about "short assignments" and suggests concentrating on writing only what can be seen through a oneinch picture frame at any given time (17).

Much of this advice is derived from their own experiences, and both Golub and Lamott use their own experiences to enhance their texts and to let readers know that they, too, experience these frustrations. Golub writes about how, desperate to find time to write in between phone calls, she sometimes takes the phone off the hook in the afternoon: 
But afterward there would be a price to pay. A repeated busy signal would drive my father-in-law, for example, crazy. The man prides himself on being a nudge. So, as soon as I would put the phone back on the hook it would ring and it would be him, telling me he had called the phone company to see if my phone was out of order. (13)

Lamott also shares her own experiences - and her paranoias. She describes how, after finishing a rough draft, she would spend the rest of the day obsessing "about getting creamed by a car before I could write a decent second draft. I'd worry that people would read what I'd written and believe that the accident had really been a suicide" (25). And while these narratives serve as examples and provide credibility to the advice being given by the authors, they also help to depict both Golub and Lamott as kindred spirits of sorts - as fellow struggling writers - rather than as "experts" who are bestowing their great wisdom on readers. Perhaps one of the reasons that both Golub and Lamott are able to maintain this collegial tone so successfully is because, while both are published novelists, neither have made millions writing.

In addition to addressing the affective aspects of the writing process, books in this category also include a discussion of the craft of writing, suggesting strategies, in the case of both Bird by Bird and I'd Rather Be Writing which focus on fiction, for developing plot, characters, and setting, as well as other elements. For example, Lamott provides several exercises for developing characters. She suggests asking questions about characters such as "Whom would they have voted for last time?" and "What would be the first thing they stopped doing if they found out they had six months to live? Would they start smoking again? Would they keep flossing?" (45). Lamott also suggests having characters describe their current circumstances to a close friend, "before and then after a few drinks" (47). The purpose of these types of exercises is to get to know the 
characters, because although "this knowledge may not show up per se in what you write [...] you need to find out as much as possible about the interior life of the people you are working with" (45). Similarly, Golub offers an instructive overview of different ways to use point of view and describes the strengths and weaknesses of narrating stories using first, second, and third person perspectives. She then provides an exercise that involves writing a story from different points of view in order to determine which one will be the most effective (117-121).

In contrast to the books in the first category, books in this second category address the issue of what to do after getting that rough draft down on paper. Indeed, both Golub and Lamott lead their readers through the entire writing process, rather than leaving would-be writers wondering how to refine and develop their writing further, as Cameron and Gray do. Golub compares revising a piece to "cooking with one of my mother's recipes": "None of this half a teaspoon here, add a cup of that. No, instead you sprinkle and taste. You keep tasting and adding, reading over and over - and over. Unlike cooking, though you get to take out." (88-89). I suspect that this interest in the revision process stems from the assumption - an assumption not present in books that focus on using writing as a means of self-discovery - that writing is meant to be shared with others, if not through formal publication then through some other means. While both Golub and Lamott include a chapter or two about publishing, Lamott also suggests other possibilities for sharing writing, such as writing a present for someone. This awareness of audience is also evident in the books about writing that I have included in the third category. 


\section{Books that focus on the craft of writing:}

The primary concern of books in this category is the craft of writing itself, and, as a result, much attention is given to elements of writing such as plot, structure, characterization, theme, and point of view. These books also include a discussion of what makes "good" writing good and often draw on examples from literature. Examples of this kind of how-to-write book include Jack Hodgins' A Passion for Narrative: A Guide for Writing Fiction and Jesse Lee Kercheval's Building Fiction: How to Develop $\underline{\text { Plot and Structure. }}$

Chapter titles such as "Setting: A Plausible Abode" (Hodgins) and "Constructing Characters" (Kercheval) clearly demonstrate both Hodgins' and Kercheval's commitment to helping readers work through the challenges facing fiction writers. Kercheval uses a construction metaphor throughout Building Fiction, writing that the elements of fiction "are the materials, framing lumber, tenpenny nails, door frames, and shingles I use to give my experiences and thoughts shape, to turn my imaginings into finished fiction" (2). Indeed, Kercheval's primary focus is on how to put these materials together in order to construct stories that "work." Similarly, Hodgins suggests that his is a book "devoted mainly to an exploration of skills" (17). Hodgins works through the entire writing process, beginning with how to find and develop story ideas, and then discusses plot and structure, and finally how to revise and polish stories. Neither Hodgins or Kercheval takes time to discuss why anyone should or would want to write. Instead, both assume an interest in writing fiction, and Hodgins goes so far as to write that "if you aren't already passionately eager to write fiction, you probably shouldn't read any further. It's going to be a lot of work" (16). 
The advice that Hodgins and Kercheval give about writing is very different from that provided by Lamott or Golub. While Lamott and Golub spend a great deal of time addressing the affective aspects of writing - especially the frustrations - and providing reassurance and encouragement, Hodgins and Kercheval spend relatively little time talking about how writers feel when they write. To use Kercheval's metaphor, both Hodgins and Kercheval are more interested in providing a blueprint for writers. Hodgins' chapter on structure provides a typical example. After first discussing what structure is and why it is important in fiction, Hodgins provides a overview of a variety of structures for both novels and short stories. Readers are cautioned against allowing an "interest in geometry" to take precedence over subject matter when choosing structure with this confession: "I once wasted five years working on a novel with disastrous results because I'd fallen in love with what I thought was a brilliant and original structure and then foolishly tried to invent a story to 'fit' it" (159). And while Hodgins uses this example from his own life in order to re-enforce his point, he doesn't expound on the frustrations he experienced during this time in the way that Lamott or Golub would have. The result is that, while the reader knows less about the personal writing habits of Hodgins and Kercheval, the blueprint of the writing process they provide is perhaps a bit more detailed than that provided by Lamott or Golub.

Both Kercheval and Hodgins use examples from other writers to illustrate the characteristics of "good" writing. Kercheval uses examples from Raymond Carver and Edith Wharton in his discussion of effective story openings (13-15). Hodgins also relies on examples from well regarded writers such as E.M. Forster and Robertson Davies, but draws on less well read writers such as Guy Vanderhaeghe and Carol Scott as well. 
These models are intended to illustrate the qualities of good writing, but they also provide credibility to the advice being given by Hodgins and Kercheval. Indeed, advice that suggests techniques that have been used by Charles Dickens or Margaret Laurence carries more weight than Hodgins' or Kercheval's word alone.

\section{Books that describe how to write "saleable" writing and then sell it:}

In contrast to both Hodgins' and Kercheval's interest in the craft of writing, the focus of the books in the final category is on the business of writing. Books in this category tend to emphasize product over process. Indeed, these books focus specifically on how to write to "saleable" writing and then sell that writing, and, as a result, these books are very conscious of the audience made up of prospective editors and publishers. The writing process is often represented as nothing more than a means to an end - a series of steps that must be completed as quickly as possible in order to have something to send off to editors. Indeed, the advice these books provide has little to do with what makes good writing and much to do with how to get someone to buy it. In other words, good writing is writing that sells. Examples of this kind of how-to-write book include Susan Page's The Shortest Distance Between You and a Published Book: 20 Steps to Success and Helen Gurley Brown's The Writer's Rules: The Power of Positive Prose $\underline{\text { How to Create It and Get It Published. }}$

Both of these examples focus on product and, as a result, don't give much attention to the writing process itself. Page's title, The Shortest Distance Between You and a Published Book, implies the importance that Page places on the finished product and on selling it to a publisher. The book is divided into twenty chapters, one for each 
step that is required to write and sell a book, and Page suggests that the same steps can be used to sell both fiction and non-fiction works (the only difference being that, in selling fiction, the book should be written before finding a publisher, while non-fiction works can be sold on the basis of a proposal alone and written after the contract is signed). Topics include writing a proposal, finding an agent, negotiating contracts, and coping with rejection letters. Yet Page has little to say about how to write the book: only ten pages are devoted to actually writing, in contrast to the nine pages spent discussing the importance of choosing a good title, which is "a critical tool for marketing your book later on" (21). Page also provides hints about how to "skip" the writing step altogether:

One alternative is to organize your material and then speak one section or one chapter at a time into a tape recorder. Have it transcribed, and then edit yourself, or hire a professional writer or editor. (45)

Similarly, Brown distills her advice into "fifty rules for first-class writing" such as "a new paragraph with a new thought should flow out of the thought of the preceding paragraph" (8) and "stick to one tense" (11). Indeed, most of this advice focuses on mechanics and seems superficial when compared to the detailed instructions provided by Hodgins and Kercheval.

In contrast, Both Page and Brown provide a great deal of advice about marketing writing to potential buyers. In the chapter titled "how to get a magazine article published," Brown describes how to write effective query letters and negotiate payment and a kill fee. She suggests that novice writers may need to be prepared to accept slightly less than the going rate until they become more established. Brown also describes the difference between onetime rights and world rights, and suggests that writers should "be prepared to give the magazine electronic rights for no additional payment" (59). While 
Brown's advice ends once the article is sold and delivered, Page provides guidance about how to see a book through the production and marketing stages after it has been sold. Much of this advice centers around working with an editor who has many books to watch over and market: Page suggests that authors be assertive about their views on marketing decisions that will affect their book, such as the choice of title and the jacket design. This advice is practical (for example, Page's advice to get to know your editor's assistant), and while much of it may be commonsense, it demystifies the production process.

\section{Sorting Through the Advice - Final Thoughts:}

Although these four categories are somewhat artificial, they do provide one way of looking at the variety of how-to-write books on the market, and of thinking about the different needs that readers may bring to these books. It is important to note that these categories are fluid, and that how-to-write books often incorporate elements of more than one category. For example, books that focus on the craft of writing often include chapters about how to sell finished pieces. None of the books I examined, however, encompass the characteristics of all four - perhaps because the perceived "purpose" of writing varies so much over the four categories, in often incompatible ways. As I suggested earlier, the representation of the writing process presented in how-to-write books depends a great deal on how the author views the purpose of writing, and this relationship warrants further attention.

A brief comparison of two different purposes for writing, evident in books discussed in the first and fourth categories above, provides an example of how opposing purposes for writing lie beneath the discussions of the writing process, making much of 
the advice provided by books in these two categories incompatible. For both Cameron and Gray, the primary purpose of the writing process is to uncover one's "true" self, and both use writing as a tool for personal growth and healing. Given this purpose for writing, the text itself has little value. Instead, it is the physical act of writing that is privileged, and the text that is produced serves only to provide a record of the writer's "path through the world" (Cameron xvi). In contrast, at the opposite end of the spectrum, both Page and Brown imply that the primary purpose of writing is to produce a text that can be sent off to editors and agents - that can be sold. Satisfaction comes from placing a piece in a magazine, or seeing your book in a bookstore window display, rather than from the act of writing itself. Indeed, these two purposes for writing - writing as a means of self-discovery and writing to earn money - are inherently at odds with each other, as one produces writing of a private nature, such as journal entries, and the other focuses on writing of a public nature, such as magazine articles. And while these two purposes, and types of texts, are not always mutually exclusive (some celebrity autobiographies come to mind), advocates of both sides would be quick to point out what was wrong with the advice given by the other. Indeed, Page and Brown would probably consider Cameron's advice to "just hang out on the page" self-indulgent, while Cameron and Gray would argue that, in order for any real personal growth to occur, the writer cannot be concerned with who might read what is written and what they might think about it.

On the other hand, in the case of books that focus primarily on the craft of writing but include chapters about selling finished pieces, two different but compatible purposes for writing are evident. Books that focus on the craft of writing, such as Hodgin's $\underline{A}$

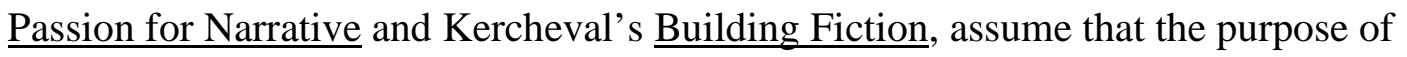


writing is to tell a story, to communicate something to someone, and that the text produced as a result of the writing process is meant to be shared. And one way of sharing a piece with its intended audience is to have it published. Thus, as this example demonstrates, the purposes evident in books included in the third and fourth categories can be complementary and often include similar goals. The difference is a matter of emphasis: books in the third category tend to privilege quality of writing and the development of skills, while those in the fourth category tend to emphasize quantity, efficiency, and profit. Similarly, books in the second and third categories - those that focus on the affective aspects of writing and those that focus on the craft - share a common perception of the purpose of writing (to communicate a message) and often differ only in their approach, with books in the second category paying closer attention to the many frustrations of the writing process than those in the third category.

While this essay has provided a broad overview of the how-to-write genre, more work in this area is needed. Indeed, a closer analysis of underlying ideologies present in the four categories of how-to-write books would, I suspect, prove interesting. Several examinations of ideologies underlying the advice given in college composition textbooks have already been done (see Brody or Faigley for an example), but no one, to my knowledge, has done a similar analysis of books about writing intended for a more general market. Examining how the perceived purpose, or reason, for writing affects the advice given by various how-to-write books more closely may provide one way of further exploring the ideologies that shape the advice given to would-be writers. It is hoped, therefore, that this essay has provided a starting point for more in-depth work. 


\section{Acknowledgements:}

I would like to thank Dr. Margaret Mackey for her guidance throughout this project. This paper is also available as part of my MLIS capping exercise (LIS 600) through the website for the School of Library and Information Studies at the University of Alberta, at http://www.slis.ualberta.ca/cap01/angela/index.html

\section{Works Cited}

Brody, Miriam. Manly Writing: Gender, Rhetoric, and the Rise of Composition. Carbondale: Southern Illinois University Press, 1993.

Brown, Helen Gurley. The Writer's Rules: The Power of Positive Prose - How to Create It and Get It Published. New York: William Morrow, 1997.

Cameron, Julia. The Right to Write: An Invitation and Initiation into the Writing Life. New York: Jeremy P. Tarcher, 1998.

Faigley, Lester. "Coherent Contradictions: The Conflicting Rhetoric of Writing Textbooks." Fragments of Rationality: Postmodernity and the Subject of Composition. Pittsburgh: University of Pittsburgh Press, 1992.

Goldberg, Natalie. Thunder and Lightning: Cracking Open the Writer's Craft. New York: Bantam Books, 2000.

Golub, Marcia. I'd Rather Be Writing. Cincinnati: Writer's Digest Books, 1999.

Gray, Dorothy Randall. Soul Between the Lines: Freeing Your Creative Spirit Through Writing. New York: Avon Books, 1998.

Hale, Constance. Sin and Syntax: How to Craft Wickedly Effective Prose. New York: Broadway Books, 1999.

Hodgins, Jack. A Passion for Narrative: A Guide for Writing Fiction. Toronto: McClelland \& Stewart, 1993.

Kercheval, Jesse Lee. Building Fiction: How to Develop Plot and Structure. Cincinnati: Story Press, 1997.

King, Stephen. On Writing: A Memoir of the Craft. New York: Scribner, 2000. 
Lamott, Anne. Bird by Bird: Some Instructions on Writing and Life. New York: Anchor Books, 1994.

Mock, Jeff. You Can Write Poetry. Cincinnati: Writer's Digest Books, 1998.

Page, Susan. The Shortest Distance Between You and a Published Book. New York: Broadway Books, 1997.

Randisi, Robert J., ed. Writing the Private Eye Novel: A Handbook. Cincinnati: Writer's Digest Books, 1997.

Reed, Janine. "Self-Orientation in 'Expressive Writing' Instruction.” Journal of Teaching Writing 13.1/2 (1994): 109-126.

\section{Selected Bibliography}

\section{Books that focus on using writing for self-discovery:}

Alberta, Susan Wittig, Phd. Writing from Life: Telling Your Soul's Story. New York: Jeremy P. Tarcher, 1996.

Aronie, Nancy Slonim. Writing from the Heart: Tapping the Power of Your Inner Voice. New York: Hyperion, 1998.

Burnham, Sophy. For Writers Only. New York: Ballantine Books, 1994.

Cameron, Julia, and Mark Bryan. The Artist's Way: A Spiritual Path to Higher Creativity. New York: Jeremy P. Tarcher, 1992.

Cameron, Julia. The Right to Write: An Invitation and Initiation into the Writing Life. New York: Jeremy P. Tarcher, 1998.

Fox, John. Finding What You Didn't Lose: Expressing Your Truth and Creativity Through Poem Making. New York: Jeremy P. Tarcher, 1995.

Gray, Dorothy Randall. Soul Between the Lines: Freeing Your Creative Spirit Through Writing. New York: Avon Books, 1998.

Maisel, Eric. Deep Writing: 7 Principles That Bring Ideas to Life. New York: Jeremy P. Tarcher, 1999.

Nelson, G. Lynn. Writing and Being: Taking Back Our Lives Through the Power of Language. Philadelphia: Innisfree Press, 1994. 


\section{Books that address the affective aspects of the writing process:}

Berg, Elizabeth. Escaping into the Open: The Art of Writing True. New York: Perennial, 1999.

Brown, Rita Mae. Starting from Scratch: A Different Kind of Writers' Manual. New York: Bantam Books, 1988.

Els, Susan McBride. Into the Deep: A Writer's Look at Creativity. Portsmouth: Heinemann, 1994.

Goldberg, Natalie. Thunder and Lightning: Cracking Open the Writer's Craft. New York: Bantam Books, 2000.

Golub, Marcia. I'd Rather Be Writing. Cincinnati: Writer's Digest Books, 1999.

King, Stephen. On Writing: A Memoir of the Craft. New York: Scribner, 2000.

Kowit, Steve. In the Palm of Your Hand: The Poet's Portable Workshop. Gardiner: Tilbury House, 1995.

Lamott, Anne. Bird by Bird: Some Instructions on Writing and Life. New York: Anchor Books, 1994.

Marshall, J. Cook. Freeing Your Creativity: A Writer's Guide How to Write More and Better Than You Ever Thought You Could. Cincinnati: Writer's Digest Books, 1992. Mock, Jeff. You Can Write Poetry. Cincinnati: Writer's Digest Books, 1998.

Ueland, Brenda. If you want to write. 2nd ed. 1938. St. Paul: Graywolf Press, 1987.

Walton, Todd, and Mindy Toomay. The Writer's Path: A Guidebook for Your Creative Journey. Toronto: Ten Speed Press, 2000.

Wooldridge, Susan Goldsmith. poemcrazy: freeing your life with words. New York: Three Rivers Press, 1996.

\section{Books that focus on the craft of writing:}

Checkoway, Julie, ed. Creating Fiction: Instruction and Insights from Teachers of the Associated Writing Programs. Cincinnati: Story Press, 1999.

Frey, James N. How to Write a Damn Good Novel. New York: St. Martin's Press, 1987. Hall, Oakley. The Art and Craft of Novel Writing. Cincinnati: Story Press, 1989. Hodgins, Jack. A Passion for Narrative: A Guide for Writing Fiction. Toronto: McClelland \& Stewart, 1993. 
Ioannou, Susan. A Magical Clockwork: The Art of Writing the Poem. Toronto:

Wordwrights Canada, 2000.

Kaplan, David Michael. Revision: A Creative Approach to Writing and Rewriting

Fiction. Cincinnati: Story Press, 1997.

Kercheval, Jesse Lee. Building Fiction: How to Develop Plot and Structure. Cincinnati:

Story Press, 1997.

Lewis, Ken. The Nuts and Bolts of Writing Fiction. Calgary: Detselig Enterprises, 1996.

Marshall, Evan. The Marshall Plan for Novel Writing. Cincinnati: Writer's Digest

Books, 1998.

Minot, Stephen. Three Genres: The Writing of Poetry, Fiction, and Drama. 6th ed. Upper Saddle River: Prentice Hall, 1998.

Novakovich, Josip. Writing Fiction Step by Step. Cincinnati: Story Press, 1998.

O'Conner, Patricia T. Words Fail Me: What Everyone Who Writes Should Know about Writing. New York: Harcourt Brace: 1999.

Stein, Sol. How to Grow a Novel: The Most Common Mistakes Writers Make and How to Overcome Them. New York: St. Martin's Press, 1999.

\section{Books that describe how to write "saleable" writing and then sell it:}

Adamec, Christine. Writing Freelance. North Vancouver, BC: Self-Counsel Press, 2000.

Bickham, Jack M. Writing and Selling Your Novel. Cincinnati: Writer's Digest Books, 1996.

Bly, Robert. Write More, Sell More. Cincinnati: Writer's Digest Books, 1998.

Brayfield, Celia. Bestseller: Secrets of Successful Writing. London: Fourth Estate, 1996.

Brown, Helen Gurley. The Writer's Rules: The Power of Positive Prose - How to Create It and Get It Published. New York: William Morrow, 1997.

Camenson, Blythe and Marshall I. Cook. Your Novel Proposal: From Creation to Contract. Cincinnati: Writer's Digest Books, 1999.

Lukeman, Noah. The First Five Pages: A Writer's Guide to Staying Out of the Rejection Pile. New York: Simon \& Schuster, 2000.

O'Neil, L. Peat. Travel Writing: See the World, Sell the Story. Cincinnati: Writer's Digest Books, 1996. 
Page, Susan. The Shortest Distance Between You and a Published Book. New York: Broadway Books, 1997.

Rozakis, Laurie E., Phd. The Complete Idiot's Guide to Creative Writing. New York: Alpha books, a division of MacMillan General Reference, 1997.

Sellers, Susan, ed. Instead of Full Stops: A Guide to Writing and Publishing Non-Fiction. London: The Women's Press, 1996.

Wylie, Betty Jane. The Write Track: How to Succeed as a Freelance Writer in Canada. Toronto: Macmillan Canada, 1998. 